\title{
Public Administration of German Space Programs
}

\section{Iryna Orlovska}

Ph.D. in Law, Associate Professor, Federation of Trade Unions of Ukraine (Kyiv,Ukraine).

E-mail: Orlovska27-09@ukr.net

https//orcid.org/0000-0001-9266-7416

\section{Kateryna Solodova}

PhD-Student, Institute of public law at the Georg-August-University Goettingen

(Goettingen, Germany)

E-mail: solodova_kateryna@ukr.net

https://orcid.org/0000-0001-9878-2802

The author of the article shows that the planning of administration of space programs in Germany is at a high level. However, the implementation of space programs requires improvement in order to attract investments from private businesses to this process. The authors prove that it is for this purpose that the system of sources of space law, on which the implementation of space programs is based, requires systematic improvement. The authors prove that in the context of globalization and the reduction of the Asian space powers lag from the European ones, only the wide involvement of private capital in the German space industry will provide competitive advantages in the market of space services.

Keywords: space programs, space science, space law, European Space Agency, German space Agency, public administration.

Received: January 24, 2018; accepted: February 26, 2019

Advanced Space Law, Volume 3, 2019: 83-96.

https://doi.org/10.29202/asl/2019/3/7

\section{Introduction}

In our article, we will develop the theory and practical aspects of the legal system of public administration of space programs of Germany. This problem is Central because: first, Germany is the leading space power of the EU and a member of ESA, which has an excellently developed space science, a variety of space technologies and the corresponding space production business, which can produce together with its partners the entire cycle of space carriers, satellites and other space objects and devices; secondly, the entry into the arena of space services of

(C) Orlovska, Iryna, 2019

(C) Solodova, Kateryna, 2019 
private space companies, as a result of which competition has increased significantly; thirdly, the significant development of fundamental and applied knowledge about space and the development of space technologies. this leads to new technological space capabilities; fourth, the gap between the norms of space law and the development of knowledge about space and engineering space technologies. Of these issues, there is some legal literature, but it reveals only certain aspects of this problem.

The paper analyzes the main space programs that exist in Germany. This analysis was carried out from a legal point of view. Further, the generalization and classification of the norms of space law on which public administration is based were identified. It was also classified summarised and the content of constituent entities of the public administration responsible for planning and carrying out the space programmes of Germany. Clarified the role and place in this system, the ESA and established the basic legal methods of influence of public administration on the objects of public management.

\section{Modern space programs of Germany}

In Germany, scientific research in outer space has reached a high level over the past 30 years. Germany in this area is recognised as the world's image. As a result, German scientists receive many orders for the implementation of the programs of the European space Agency (ESA) and the EU as a whole, as well as perform numerous orders from the space agencies of the United States, China, Russia and Japan. This, along with other traditional German values, provides the German economy with a large number of innovations that are directly or indirectly related to space exploration. After all, technological progress requires new knowledge. However, further progress could be achieved only if the public administration of space programmes was effective.

In Germany, there is a German space program and an innovative program, as well as special subjects of space activities in Germany that carry out the programs of the European Space Agency and the European organization for the operation of meteorological satellites.

In November 2010, the Federal government of Germany adopted the space strategy, which is the basis of the German national space program. It consists of a comprehensive public administration of the use of outer space by the subjects of space activities of Germany and its allies, primarily ESA and the participating countries. Such cooperation is very important in the context of globalization. It is only thanks to the joint development of space technologies that modern global communications work effectively, navigation of land, sea and air transport is carried out, and the global Internet system functions. The strategy defines that the main value of German science is "knowledge". As for the poor natural resources of the countries, which is Germany knowledge is the main strategic factor. Science and research are the basis of technological innovation and an economical source of economic capacity-building of the state and social security of citizens. And the exploration and use of outer space is a factor that contributes to the creation of new knowledge [Die Raumfahrtstrategie, 2012.].

The German space programme has undergone a broad process of discussion with scientists, representatives of the national space industry and ESA. In General, Germany's space program is implemented in eight main areas.

The first direction is the observation of our planet with the help of artificial satellites, which are in various near-earth orbits. German scientists successfully use information data from remote sensing satellites. This makes it possible to detect changes on the earth's surface, oceans 
and atmosphere, develop measures to protect the environment, and create accurate maps and models of climate and environmental dynamics. Earth observation satellites provide rapid fixation and dynamics of development of dangerous natural and man-made phenomena - earthquakes, floods, fires, oil spills and others. Thanks to this information about the disaster in time to receive rescue services. Remote sensing of the Earth through satellites allows you to create accurate digital maps of the earth's surface, as well as provide daily weather forecast, navigation of aviation, sea, road and rail transport. Satellite earth observation also provides observations of the ozone layer and phenomena that contribute to global warming. They provide the necessary information to the government agencies and the planning system measures coverage and quality of mobile communications [Programme, 2019].

The second area is the provision of high-quality and affordable satellite communications. The German satellite communications program covers the entire range of information technologies that can be provided by telecommunication satellites. The advantage of satellite communications is primarily the almost global coverage of the signal by geostationary satellites. Now the special attention of German scientists is focused on the development of future global multimedia satellite systems. The satellite telecommunications program is aimed not only at fulfilling important social tasks, but also at the development of the German economy. After all, it covers measures from development to production and sale of high-tech industrial products. Thanks to the targeted policy of Federal funding in this area, the German industry was able to win a significant part of this market [Raumfahrttechnologie, 2019].

The third direction is to provide high-quality and comprehensive satellite navigation. German scientists and industry contribute to Galileo's European independent and alternative GPS satellite navigation system. This system offers European consumers high quality, virtue and generally strengthens European sovereignty. Galileo is a great and innovative European project with high economic potential [Navigation, 2019]. The fourth direction, the development of academic programs of space research. According to which German scientists in close cooperation with scientists from other countries analyze and summarize scientific knowledge about stars and galaxies. Put forward and prove and refute hypotheses on the formation and evolution of celestial bodies and the Universe as a whole [Extraterrestrics, 2019].

The fifth direction is research in open space. In this direction, German scientists focus on four thematic priorities: the problem of origin, development and boundaries of life; the study of the fundamental laws of nature and physics; the development of innovative methods of prevention, diagnosis and rehabilitation in medicine; the design of new materials for innovative production processes. German scientists in this field carry out programs of the European Space Agency and space agencies of the USA, China, Russia and Japan. That provides German science with a wide range of outstanding scientific achievements and provide German industry with a large number of innovations.

The sixth direction is the development of space carriers. Space carriers play a key role in the German and European space strategy. This program provides a reliable, flexible and competitive system of unimpeded access of German scientists to outer space. Now the implementation of this program provides a line of space noses Ariane. They start from the spaceport in French Guiana. In order to remain successful in international competition, Ariane is constantly evolving. The development of the Ariane carrier system is funded by all ESA Member States. Today, Germany plays a leading role in ESA regarding the manufacture of tanks for missiles (liquid storage), control systems and thermal protection of carriers, as well as providing specialized facilities for the testing of units and parts of missile carriers [Trägersysteme, 2019]. 
The seventh direction is the development of manned Astronautics, which is implemented at The International Space Station, which is the largest scientific and technical project in outer space. The contractual basis for cooperation at the International Space Station is the international agreement between the governments of the partners involved, which was signed in Washington on 29 January 1998. The parties to the agreement are the USA, Russia, Japan, Canada and ESA. Germany is the most important partner of the ISS in Europe, as it is the largest contributor to the development of space programs, funding about 40 percent of ESA programs).

The eighth direction is the development of space systems and robotics technologies. Future space missions place higher demands on the technological equipment of spacecraft. They should be more Autonomous, have an improved automatic control system, more powerful traditional and electric drives, more space for the payload by miniaturization of components. Automation and robotics are the leading potential of future comic missions. Intelligent robots will become indispensable helpers of astronauts. Works reduce costs and risks by helping astronauts perform space work. Largely Autonomous robots will land on celestial bodies and explore them on their own. High mobility, precise manipulation and the possibility of Autonomous operation of the robot system will be a decisive factor for solving space problems. This leads to the fact that the developed and developed space robotics will become an important driving force of innovation for terrestrial technologies [Programme, 2019].

The implementation of these programs enables Germany to have unlimited access to hightech products, critical space technologies and components that are important for the implementation of its own political, social and economic interests of Germany and the EU as a whole.

Thus, the German strategy for the exploration and use of outer space is the creation of new knowledge as a strategic resource. This is done through the implementation of eight main areas that German scientists and the space industry implement in cooperation with the subjects of other States. At the same time, many of them, the contribution of German scientists, German technology and German business is leading.

\section{Normative regulation of implementation of space programs of Germany}

Regulatory implementation of space programmes Germany consists of international space law, European space law and national German legislation.

There is no point in analyzing international space legislation in this article in detail. After all, these norms were adopted more than fifty years ago. They are analyzed in detail and repeatedly in the legal literature on international space law. The main drawback of international space legislation is that they are not protected by sanctions of legal norms. No "space" police have been established to protect them from violations. In other words, compliance with international space law depends on a combination of international politics, the global economy and public opinion. Although theoretically the norms of international space law have priority over the national norms of space law of any state.

This is confirmed by the fact that, after the adoption by the international community of the fundamental norms of international space law, none of the States formally violated them in the sphere of law-making and in the practical use of outer space. In particular, it should be emphasized that the legislative power, the government on other subjects of space activities in Germany strictly adhere to international space legislation. 
With the development of space technologies and the entry into outer space of private space companies, international space legislation requires changes and additions. However, due to the fact that there is no political will of the space powers to mutually infringe on their interests for the common good of mankind, it is not necessary to expect that international norms of space law will be improved.

Accordingly, in recent years, sovereign States have taken the path of developing and producing new space norms, which are approved by national parliaments and on their basis in subordinate legislation. This is not very good, because it can lead to "space" conflicts among independent States.

However, the way of formation of new national space norms is better than the lack of legal regulation in this sphere in General. After all, such norms, unlike international space norms, are clearly protected by sanctions of both administrative and criminal law norms. Law enforcement agencies and courts operate in sovereign States with a view to bringing them to legal responsibility for their violation.

When to use outer space involved private companies, according to the new actual steel spheres of administrative control that apply to the subjects of space activities arising from international obligations of the state, in particular: the question of fixing the nationality of space vehicles; problem of jurisdiction of international space projects and the related issues of responsibility for harm in connection with the implementation of space activities; protecting the rights of investors in relation to space objects and spacecraft; environmental protection in the process of space activities; to combine international responsibility of States with the property liability commercial structures - direct participants of space activities, for the damage caused to the environment as a result of such activities; the impact of commercialization and privatization of space activities to the public sector services in this field; the establishment of effective mechanisms for the settlement of disputes arising in the field of space activities, etc [Bagus, 2015].

Consequently, the national space legislation of Germany is formed by the unconditional adoption of the basic principles and norms based on strict and soft laws, international standards of international space law and the best legislative practice of other space powers.

The development of space technologies has facilitated the use of outer space for various space "actors" other than States themselves. After all, they are responsible for the activities of their non-state space companies in space. This leads to the fact that space powers should adopt appropriate national space laws to regulate space activities within their jurisdictional responsibility. National legislators must cope with the ever-changing spectrum of space technologies if they are to continue to participate in space activities. It is necessary to find the right balance between the legal restrictions imposed on non-state actors in space activities and the promotion of their scientific and innovative potential [Freeland et al, 2018].

The main legislative regulation of space programs is carried out through the implementation of the rules of law concentrated in the laws on the transfer of administrative tasks in the field of space flights, telecommunications and the protection of satellite data.

The primary national normative act in the field of public administration of space programs is the Federal law on the transfer of administrative tasks in the field of space flights. It determines that the highest Federal authorities responsible for space Affairs grant the German aerospace centre the authority to perform administrative tasks in the field of space flight. This Agency carries out public administration of the space industry on its own behalf, without coordination with the relevant Ministry in the forms and methods that are inherent for the subjects 
of public law. Thanks to this law, the future of the German space industry is inextricably linked to space programs through appropriate planning. It is determined that the implementation of space programs should be carried out primarily through the involvement of German space companies in this process and through the conclusion of contracts with other countries, or with individual foreign organizations with the necessary experience of space activities on the basis of the implementation of German grants [Gesetz, 1990].

The law on telecommunications [Telecommunications, 1999] has the objective of implementing independent, on the basis of competition, regulation of activities of economic entities in the field of telecommunications, provision of effective telecommunications infrastructure and the provision of quality telecommunication services throughout the country. The implementation of the law is carried out in various ways. First, by supporting the interests of consumers in the field of telecommunications, to provide consumers with quality information content. The interests of vulnerable social groups, in particular persons with disabilities, older persons and people with special social needs, must be taken into account. Secondly, ensuring equal competition and promoting a competitive telecommunications market and networks in all places of Germany without exception and for all persons. Third, the accelerated development of high-performance public telecommunications networks of the next generation. Fourth, the provision of telecommunication services in public facilities and places. Fifth, public security interests.

Consequently, the law on telecommunications is a significant normative act for individuals and legal entities in the field of ensuring the provision of high-quality telecommunications services using space technology in Germany.

The law on the protection of satellite data (2007) regulates the operation of earth remote sensing systems for the needs of German citizens, German legal entities and associations of citizens, as well as foreign legal entities subject to the regulatory influence of German law. Germany is the first country in Europe to have such regulation [Gesetze, 2007].

The act in question provides for measures for the safe use of remote sensing data for civil, including commercial, purposes. Regulates the admission of scientists and commercial users to this data. Provides national security and foreign policy interests of Germany, as well as the EU, NATO and other allies. It gives a categorical legislative definition of what is meant by "high-quality earth remote sensing systems". In General, the law on the protection of satellite data provides such a legal regime that the earth observation data received from German satellites or ground stations on earth does not jeopardize the national security of Germany and at the same time does not become an obstacle for scientists and the civil German sector of economy and social life.

As for the by-laws and regulations, the primary here is the Charter of the German aerospace centre. According to which it formally refers to legal entities of private law, organized and registered as an Association. However, according to the above laws, the analyzed Agency is practically a subject of public law. After all, in accordance with the delegated in the law On the transfer of administrative tasks in the field of space flights, the powers of this Association are delegated to the Executive power in the space industry.

Thus, the German aerospace centre is practically a subject of public administration, which carries out public administration of the German space industry. According to the Charter, the governing bodies of the Association are the General Assembly, the Senate, the space Committee, the Board and the scientific and technical Council.

To analyze the Statute prescribed high demands on employees, DLR. Which are required to comply with the regulations and rules of the company, as well as ethical principles defined in 
the company's values. These include respect for human rights, labour standards, health, the environment and the fight against corruption. In addition, DLR has agreed to shared values such as respect, fairness, appreciation, tolerance, team spirit, honesty, transparency and acceptance in the DLR guidelines throughout the company. The code of conduct, guidelines and various sector compliance rules include certain values of daily work and business practices.

Consequently, the legislative support for the implementation of the German space program is characterized by pragmatism and specificity. In the norms of national space law, the legislator, through the law, delegated most of the duties and rights to perform it to a non-state structure, a kind of public organization DLR. Public administration in the middle of which is carried out on the basis of the Charter of the Association. We believe that a national law on the exploration and use of outer space should be developed and adopted in order to ensure the systematic and dynamic development of space exploration and use with the involvement of private investment. According to which any private company that meets the requirements of national security of Germany, its allies and security conditions can obtain in the prescribed manner licenses for the production, launch and operation of launch vehicles, satellites and the right to establish their own spaceports.

\section{Subjects of public administration of space programs of Germany}

Germany is a powerful scientific space state with a highly developed competitive industry. It is a democratic, legal and social state with a well-developed civil society. All these factors make a positive aspect in the formation and operation of the system of public administration entities that carry out the implementation of space programs. After all, this system is not dominated by state actors of public administration.

The Central Executive body is traditionally located at the top level of the subjects of public administration of space programs. This is the Federal Ministry of economy and energy (BMWi). It contributes to the development of space activities at the national and European levels. BMWi is responsible for the implementation of economic policy objectives based on the principles of social market economy. The Ministry ensures the development of scientific infrastructure for innovation. Special attention of the analyzed Ministry is focused on the support of small and medium-sized enterprises working in the conditions of severe competition of globalization. National projects of the European space Agency are implemented through BMWi and DLR is under its management influence.

DLR is the most significant specialized subject of public administration, which carries out public administration for the implementation of space programs. It is a research center of the aerospace industry and the space center of Germany. The space Agency develops and executes the German space programme on behalf of the German Federal government and brings together all German space measures at the national, European and international levels. This Agency has significant research achievements in the field of space, energy, transport and security. It is integrated into national and international cooperative enterprises. In addition, the Federal government is responsible for engaging other national project management agencies in this activity. DLR has about 8,000 employees in 20 German cities and has offices in Brussels, Paris, Tokyo and Washington [DLR, 2019].

Public organizations play a leading role in the system of public administration of space programs. Thus, the Federal Association of the German aerospace industry (BDLI) is a strategically important subject in the space field. Thanks to which Germany and ESA play a leading 
global role in the exploration and use of outer space. BDLI has more than 230 members and represents the interests of the space industry, characterized by international technological leadership worldwide. This ensures that the German aerospace industry is not only a source of new space technologies, but also an important employer. After all, the aerospace industry employs more than 100 thousand highly skilled workers.

The main objectives of BDLI are to ensure the interests of aerospace business in political circles (it is officially accredited to the German Bundestag), in the Executive authorities of Germany, in foreign offices, as well as aerospace organizations in Germany abroad. This Association is the brand owner of the International aerospace exhibition ILA in Berlin. She is a member of leading European space organizations AeroSpace and Defence Industries Association of Europe and the Federation of German industries.

German aerospace society Lilienthal - Oberth e.V. (DGLR) is one of the oldest public organizations in Germany and the only Association that is represented by its members in all aerospace fields - from industrial production to the Central Executive authorities. It provides information assistance to all persons engaged in space activities on a professional basis or as individuals. It also promotes national and international exchange of experience between industrial space companies, authorities, research institutes and universities. [Die Raumfahrtstrategie, 2012.].

The subject of international law, the European organization for the exploitation of meteorological satellites (EUMETSAT), of which Germany is a member, has a significant impact on the implementation of space programs. The aim of the organization is to collect and process accurate and reliable satellite data on weather, climate and weather environment. To provide satellite data, images and products related to weather and climate, 24 hours a day, 365 days a year - to the national meteorological services of the member countries in Europe, and other users worldwide. The Supreme body of public administration of EUMETSAT is the Board, which is subordinate to the Director General and Executive Director. The Council consists of representatives of States parties that co-Finance the programmes and activities of EUMETSAT [EUMETSAT, 2019].

The next subject of public administration is the parliamentary group of the aerospace service in the German Bundestag. It exchanges information between representatives of German politics, business and science. And it ensures close contacts with members of other European parliaments in this area.

In addition to the entities that are funded from the Federal budget and that provide individuals and legal entities with a variety of administrative, educational and training services related to space exploration are: planetariums and observatories; German space Museum; German Space Travel Exhibition in Morgenröthe-Rautenkranz; several famous and well-known museums related to space exploration; archive of space history (Bremen).

A separate line should be allocated to research institutes, which make a leading scientific contribution to the study of outer space and the development of new space technologies. First of all, it is the Max Planck Society (it. Max-Planck-Gesellschaft zur Förderung der Wissenschaften e.V., MPG), which is the most successful research organization in Germany - since its Foundation in 1948, it has 18 Nobel prize winners. This puts it on a par with the best and most respected research institutions in the world. Each year, more than 15,000 publications in world-renowned journals attest to outstanding scientific work at Max Planck institutes, many of which may be among the most cited publications in their respective industries. Currently, 83 scientific institutes of max Planck conduct fundamental research in the field of Natural Sciences, biology, Humanities and Social Sciences. 
In particular, there are several institutions in the Max Planck Society system. Institute of solar system research, which aims not only to describe the processes in the Solar system in theoretical models but also to simulate them in computer models. Institute of astronomy, which explores: How do stars and planets appear? What are the properties of planets orbiting other stars? How do galaxies appear and how have their properties changed in space history? At the same time, most of the scientists of this Institute work in the scientific and technical sphere. The Institute of astrophysics studies the evolution of stars and the structure of stars, the physics of supernovae, high energy astrophysics, radiation processes in space, the structure, formation and evolution of galaxies, and the large-scale structure of the Universe, the early Universe, and cosmology. At the Institute of gravitational physics, researchers study the entire spectrum of General relativity and beyond: from the gigantic dimensions of space to the unthinkably small dimensions, string theory.

Scientific and educational institutions, which are part of universities, make a certain contribution to the implementation of space programmes. Among them are: the Institute of Astronomy of the University of Bonn; the Department of aerospace engineering of the University of Applied Sciences; the faculty of aerospace engineering of the University of the Federal Armed Forces; the Faculty of aerospace engineering and geodesy of the University of Stuttgart; the Institute of aerospace engineering Of the Technical University of Berlin; the Institute of air and space law of the University of Cologne; the Institute Of planetary geodesy of the Dresden University of technology; The Institute of space systems of Stuttgart; the Institute of space science of the University of Berlin; the Centre for applied space technology and microgravity of the University of Bremen.

Positive in Germany is that theoretical research in the field of space activities have an unprecedentedly high percentage of practical implementation in production. This is provided by powerful modern manufacturing enterprises that produce space industrial products.

Among them, it is advisable to highlight the company Airbus Defence and Space, which is the second largest space company in the world. It employs about 40 thousand employees. It produces tactical and strategic aircraft, multifunctional air tankers and advanced combat aircraft. The annual sales volume of industrial products is about 14 billion euros [Airbus, 2019]. Carl Zeiss company, which specializes in the production of semiconductors and optics, including for the space industry. It is present in more than 40 countries with more than 30 production sites. The Corporation is comprised of 25 research objectives [ZEISS, 2019].

Space company Jena-Optronik is focused on commercial and institutional programs in the following space areas: production of positioning sensors for satellites and probes; devices for earth observation and universe research; software and data processing. MT Aerospace is an aviation and aerospace company that has supplied key components for the European ARIANE-5 launch vehicle, spacecraft, satellites and radio telescopes. OHB System AG is one of the three leading space companies in Europe. The main activities of this company are nearearth and geostationary satellites.

Therefore, the subjects of public administration in carrying out the space programmes of Germany are divided into 1) state; a) the Central body of Executive power of General competence - the Federal Ministry of economy and energy; b) a special Executive authority of the German aerospace centre; 2) the public space organizations - the Federal Association of German aerospace industry and the German aerospace society; 3) international space organisations - the European organisation for the exploitation of meteorological satellites; 4) a consultative Advisory bodies of the European Parliament — the parliamentary group for 
aerospace to service in the Bundestag; 5) planetariums and observatories, museums of cosmonautics and space exhibition; 6) research institutes space research and scientific-educational institutions, which are part of universities; 7) the company's business, implementing the scientific theoretical developments in practical production.

\section{Features of German aerospace centre membership in the European space agency}

According to Patrick Michielsen States should apply rigorous but pragmatic approaches to UN space treaties and their key concepts to cover transboundary space activities, for example, through the conclusion of two - or multilateral space agreements [Michielsen, 2016].

It is behind this rule that the European Space Agency, the main regulator and monopolist in the European space market, was created. Its administrative mission is to manage the development of the European space industry and ensure that public investment provides a positive socio-economic impact on European citizens. Formally, ESA is an international organization with 22 member States: Belgium, Czech Republic, Denmark, Estonia, Finland, France, Germany, Greece, Great Britain, Ireland, Italy, Luxembourg, Netherlands, Norway, Austria, Poland, Portugal, Romania, Sweden, Switzerland, Spain and Hungary. Canada participates in some projects through a cooperation agreement. Bulgaria, Latvia, Lithuania, Malta, the Slovak Republic and Slovenia are "European States cooperating".

This list quickly reveals that not all EU Member States are also ESA members - and Vice versa. In fact, ESA is a fully independent organization. Of course, it maintains close ties with the EU through the ESA/EU framework agreement and carries out overall coordination of financial and intellectual resources of the participants, which allows for the implementation of ambitious world-class projects.

More recently, member States have been demanding that ESA implement more space research for the benefit of citizens, public entities and businesses of member States. To that end, the practical use of space activities should be improved by adjusting the European space programme and coordinating its implementation at the European and national levels with a focus on the end-users of space services. Enhancing the relationship between military and civilian space programmes and technologies related to institutional competence. Closer integration and development of joint space activities of the countries participating in the practical orientation.

ESA has a number of institutional entities that, through public administration, carry out space programmes related to space activities, including the European space research centre; the European centre for space operations; the European Institute for space research; the European centre for astronauts, located in Cologne, Germany.

In addition to internally management activities ESA carries out external activities, which were signs of international relations, in particular concerning the organization of membership in ESA of new members; participation of States not members of ESA, individual optional programmes of ESA; ESA's participation in the activities of other international, primarily European organizations.

Combining the resources and know-how of each country makes it possible to implement programmes and projects that no member country has ever been able to create on its own. In this context, the GermanAerospace Agency represents the interests of the Federal Republic of Germany in ESA. Switzerland's interests are represented by the Swiss space office. The aero- 
space activities Agency of the Austrian research assistance Agency FFG represents Austria in ESA on behalf of the Federal Ministry of transport, innovation and technology.

The highest technological level of practical use of space technologies is manned flights of astronauts of ESA Member States. This is now being done at the International space station. The ESA space mission programme includes space missions (now exclusively to the ISS); the introduction and operation of unmanned reconnaissance missions to other planets and the moon; earth observation, science and telecommunications; launch vehicle design; and the great space maintenance centre, the Guayana space centre in Kourou, French Guiana.

The official representative of Germany as a member state of ESA is the German Space Agency. It directly administers the public administration of ESA space programmes in certain areas, sectors and individual space-related industries, under delegated legislative authority. Take into account the fact that the order for carrying out the space programmes of ESA are distributed depending on the share of contributions of member States, DLR is making a leading contribution to the implementation of space programs of ESA. After all, the amount of financial contributions from Germany is the whitest among all ESA Member States.

The effectiveness of German developments in the ESA system is realized through the system of joint public administration of space activities. For example, thanks to the cross-planning of ESA and the German space centre for the coordination of their activities for practical implementation, Germany is a world leader in the development of laser terminals.

Thus, the existing regularity of space exploration on the part of many States of the planet Earth has led to the need for a common policy in this area. The German space championship is undeniable, so the next priority is to improve scientific research on the use of outer space.

It should be noted that, through targeted technological developments in this area of space management, it provides the basis for independent policy action and at the same time strengthens the cooperation and competitiveness of German companies and research institutions. In addition, through DLR, Germany is harmonizing with ESA the European space travel technology base for the next decade. Space technologies should be able to provide Autonomous or semi-Autonomous space infrastructures. These requirements require maximum creativity from engineers and scientists. This applies to launchers, satellites and spacecraft, as well as the International space station and future research missions.

Thus, DLR, as the representative of Germany to ESA, prepares and implements space programmes in the amounts determined by the proportion of the financial contribution. In particular, the European centre for space operations, the European centre for astronauts and the Centre for space control are located on German soil. The implementation of the joint ESA programmes on German equipment in the special research objects located on the territory of Germany carried out testing of rocket engines and satellites, stations of space communication.

The ever-increasing number of spaceships in orbit has become a serious security problem, both in space and on earth. To prevent these challenges have been created by the German national centre of space monitoring of the situation in which the responsibility of providing a safe space flight and to prevent the abandonment in outer space debris.

So, German space science the German space industry in the ESA system makes a great contribution to improving the living conditions of people throughout Europe. They play a leading role at the European level to improve the functioning of business, science, politics and society. However, they do not want to rest on their laurels, and therefore funding for 
research and practical space activities is being carried out. DLR focuses its work on the implementation of relevant ESA space research programmes and missions. It coordinates national and international space projects in coordination with scientific institutions, business and ESA.

\section{Tools for public administration of space programs}

As already mentioned above, DLR is a public organization to which the Federal law of Germany entrusted the functions of the space program. This Association has established itself as an active management organization, which makes an important contribution to raising the high standard of living, science and security in Germany and Europe for many years and in various fields.

It is the planning of both space programs and the planning of their implementation that is the first tool of public administration. As an example, government planning to support space research aimed at projects with real economic opportunities for the development of the industry. Accordingly, this allows firms operating in the space sector to develop the potential of the space industry in the form of new commercial products and services. This not only strengthens employment in the high-tech sector but also creates new jobs [Bulmahn, 2001:12].

The conclusion of international treaties is an external international method of public administration in the implementation of space programmes. For example, on December 12, 2017, the German aerospace centre, the Japanese Space Agency JAXA and the Japanese Institute for environmental research concluded an agreement on cooperation on the use of remote sensing of greenhouse gases. Remote observation of greenhouse gases is important not only for global monitoring of the "introduction" of carbon and methane into the atmosphere but also for determining the average rise in air temperature and conclusions on climate change.

National legal norms of space law in Germany provide that the main legal means of influencing space relations, which are applied by the public administration, are: licensing of the activities of the operator; establishment of the obligations of the operator, including with regard to documentation — registration procedures, provision of information; implementation of control and Supervisory activities; establishment of taxes and other fees.

A separate line should be allocated to the implementation of positive and coercive measures, etc. The positive means should be attributed to the educational activities of the centre. For example, the German aerospace centre in Bonn opened its doors to the public on 16 June 2019. When a variety of visitors who are children, their parents and persons of other age categories are happy to hear first-hand about public, innovative, technological, environmental, security, educational and international information about space research and use.

A significant way of positive implementation of its competence by the German Aerospace Agency is the holding of conferences and exhibitions. For example, in Vienna from 18 to 21 June 2018, scientists, engineers, diplomats and officials from around the world met at the UN Conference for the "UNISPACE + 50" conference. The event was held on the occasion of the anniversary of the first UN Conference on the exploration and peaceful use of outer space 50 years after the first UN space conference in 1968. This conference laid the Foundation for the agenda of "Cosmos2030" - the basis for global cooperation in space research for the benefit of mankind. 


\section{Conclusions}

In this article, we have covered the issue that makes up the system of public administration through the planning, approval and implementation of space programs in Germany. These issues have not been comprehensively disclosed by scientists in scientific legal literature. We have summarized the plans and the corresponding further directions of implementation by special subjects of public administration of the delegated Executive powers in the space industry. To this end, it was clarified the normative regulation in this area, which is based on the norms of international space law, the norms of European space law and the national norms of German law. In the latter case, these rules have found their external design in the form of Federal laws and regulations, primarily the Charter of the German Space Agency. Considerable attention was focused on the classification and legal status of public administration entities that directly implement public administration of space programmes. The peculiarities of DLR membership in the European Space Agency were analyzed separately

However, we understand that in one article, even with a large volume, it is impossible to thoroughly disclose the public administration of space programs of such a highly developed state in science, technology and business as Germany. In the following article, we will focus on the legal status of the German Space Agency and the directions of its improvement, taking into account the new possibilities of space technologies and the entry into the market of space services of private space companies.

\section{References}

Airbus. Deutsche Gesellschaft für Luft und Raumfahrt - Lilienthal-Oberth e.V. 2019. https:// ru.linkedin.com/company/dglr

Bagus, Ida, Rahmadi Supancana. How the Progressive Development of Outer Space Law Affects the Formulation of National Space Legislation: The Experience of Indonesia. Air and Space Law, 2015. http://www.kluwerlawonline.com/abstract.php?area=Journals\&id=AILA2015009

Bulmahn, Edelgard. German Space Programme. Bundesministerium für Bildung und Forschung, 2001. https://www.dlr.de/dlr/Portaldata/1/Resources/documents/drp-engl.pdf

Bundesrecht konsolidiert: Gesamte Rechtsvorschrift für Weltraumgesetz, Fassung vom 27.07.2019. https://www.ris.bka.gv.at/GeltendeFassung.wxe?Abfrage=Bundesnormen\&Gesetzesnummer $=20007598$

Die Raumfahrtstrategie der Bundesregierung. Für eine zukunftsfähige deutsche Raumfahrt, 2012. https://www.bmwi.de/Redaktion/DE/Publikationen/Technologie/zukunftsfaehige-deutsche-raumfahrt.pdf?_ blob=publicationFile $\& v=8$

DLR at a glance, 2019. https://www.dlr.de/dlr/en/desktopdefault.aspx/tabid-10002/\#/DLR/ Start/About

EUMETSAT. We are the European Organisation for the Exploitation of Meteorological Satellites, 2019. https:/www.eumetsat.int/website/home/AboutUs/WhoWeAre/index.html

Extraterrestrics. Raumfahrtmanagement, 2019. https://www.dlr.de/rd/desktopdefault.aspx/tabid-2206/3367_read-5042/

Freeland, Steven, Kirsty Hutchison, and Val Sim. How Technology Drives Space Law Down Under: The Australian and New Zealand Experience. Air and Space Law, 2018. http:// www.kluwerlawonline.com/abstract.php?area=Journals\&id=AILA2018010 
Gesetz zur Übertragung von Verwaltungsaufgaben auf dem Gebiet der Raumfahrt (Raumfahrtaufgabenübertragungsgesetz — RAÜG), 1990 https://www.gesetze-im-internet.de/ ra_g/BJNR010140990.html

Gesetze zum Schutz vor Gefährdung der Sicherheit der Bundesrepublik Deutschland durch das Verbreiten von hochwertigen Erdfernerkundungsdaten (Satellitendatensicherheitsgesetz - SatDSiG) vom 23. November 2007 (BGB1. I S.2590).

Michielsen, Patrick. The Belgian Space Act: An Innovative Legal Safeguard to Boost the Space Industry. Air and Space Law, 2016. http://www.kluwerlawonline.com/abstract. php?area=Journals\&id=AILA2016009

Navigation. Raumfahrtmanagement, 2019. https://www.dlr.de/rd/desktopdefault.aspx/tabid-2114/3078_read-5014/

Programme und Missionen. Das DLR Raumfahrtmanagement, 2019. https://www.dlr.de/rd/ desktopdefault.aspx/tabid-2105/

Raumfahrttechnologie und Raumfahrtrobotik. Satellitenkommunikation, 2019. https://www. dlr.de/rd/desktopdefault.aspx/tabid-2115/3073_read-5041/

Schematic overview of national regulatory frameworks for space activities. A/AC.105/C.2/2014/ CRP.5, 2014. http://www.unoosa.org/pdf/limited/c2/AC105_C2_2014_CRP05E.pdf

Telecommunications (Data Protection and Privacy) Regulations 1999. UK Statutory Instruments, 1999. №. 2093. https:/www.legislation.gov.uk/uksi/1999/2093/contents/ made

Trägersysteme. Raumfahrtmanagement, 2019. https://www.dlr.de/rd/desktopdefault.aspx/tabid-2208/3370 read-5044/

UNISPACE+50. 18 - 21 June 2018. M Building, Vienna International Centre, Vienna, Austria, 2018. http://www.unoosa.org/oosa/en/ourwork/unispaceplus50/index.html

ZEISS im Überblick, 2019. https://www.zeiss.de/corporate/ueber-zeiss.html 